\title{
PENGARUH PEMAHAMAN NILAI DASAR 'ANEKA' TERHADAP PEMBENTUKAN SIKAP PESERTA LATSAR CPNS PADA BALAI DIKLAT KEUANGAN MALANG
}

\author{
Achmat Subekan1) \\ Azwar Iskandar2) \\ 1) Balai Pendidikan dan Pelatihan Keuangan Malang \\ 2) Balai Pendidikan dan Pelatihan Keuangan Makassar \\ e-mail: achmatsubekan@gmail.com
}

\begin{abstract}
The purpose of this research is to know the effect of the understanding of five fundamental subjects of basic training on attitude of partisipants in conducting their task and function as public servant. The subjects are accountability, nationalism, public ethics, commitment to quality, and anti-corruption (ANEKA). This research also want to know which subject that have biggest effect on participant's attitude. This research use random sampling technique and multiple regression analysis. Data was collected by questionnaire. This research find that the five subjects of training have positive and significant effect on participant's attitude simultanously. In partially, each of five subjects have different effect (coefficient). Nationalism, public ethics, commitment to quality, and anti-corruption have positive and significant effect. While subject of accountability has negative effect, but not significant. The subject of commitment to quality gives the strongest effect on building and developing participant's attitude as public servants. The recommendation, the five subjects are need tougth in basic training. Specially, for subject of accountability have to developed again so give positive and significant effect. The developing are about curriculum, substance of subject, and model or method lecturing used. Moreover, the subject of nationalism, public ethics, commitment to quality, and anti-corruption have to tought regularly.
\end{abstract}

Keywords: basic training, ANEKA, public servant, attitude

Abstrak: Penelitian ini bertujuan untuk mengetahui pengaruh pemahaman materi pembelajaran lima nilai dasar (akuntabilitas, nasionalisme, etika publik, komitmen mutu, dan anti korupsi) terhadap sikap peserta pelatihan dalam mengemban fungsi dan tugas. Selain itu, penelitian ini juga hendak mengetahui pemahaman materi dasar mana yang memberikan pengaruh terbesar terhadap sikap peserta Pelatihan Dasar (Latsar) CPNS. Dengan menggunakan teknik random sampling dan Regresi Linier Berganda melalui instrumen penelitian berupa kuesioner, penelitian ini menemukan bahwa pemahaman materi nilai dasar (akuntabilitas, nasionalisme, etika publik, komitmen mutu, dan anti korupsi) secara simultan memiliki pengaruh yang positif dan signifikan terhadap pembentukan sikap peserta Latsar. Sementara itu, secara parsial, kelimanya memiliki besaran pengaruh (koefisien) yang berbeda-beda. Di antara kelimanya, hanya pemahaman akan materi akuntabilitas yang memiliki pengaruh negatif, tetapi tidak signifikan, sedangkan empat variabel bebas lainnya memiliki pengaruh yang positif dan signifikan. Materi Komitmen Mutu memberikan pengaruh paling besar terhadap pembentukan dan penguatan sikap peserta dalam melaksanakan tugas/fungsi sebagai PNS. Rekomendasi yang dapat diberikan dalam penelitian ini adalah bahwa mata pelajaran Akuntabilitas perlu dilakukan perbaikan sehingga memberikan pengaruh yang positif dan signifikan dalam 
mendukung pembentukan dan penguatan sikap peserta Latsar. Perbaikan tersebut perlu dilakukan baik terhadap kurikulum, substansi materi, maupun model atau metode pembelajaran yang digunakannya. Selain itu, mata pelajaran nasionalisme, etika publik, komitmen mutu, dan antikorupsi perlu dipertahankan dan terus dikembangkan model pembelajarannya sehingga dapat memberikan pengaruh yang lebih besar dalam membangun sikap peserta Latsar.

Kata kunci: latsar, ANEKA, CPNS, sikap

\section{PENDAHULUAN}

Dalam rangka melaksanakan cita-cita dan mewujudkan tujuan negara, sesuai dengan Undang-Undang Nomor 5 Tahun 2014 Tentang Aparatur Sipil Negara (ASN), perlu dibangun Aparatur Sipil Negara (ASN) yang memiliki integritas, profesional, netral dan bebas dari intervensi politik, bersih dari praktik korupsi, kolusi, dan nepotisme (KKN), serta mampu menyelenggarakan pelayanan publik bagi masyarakat. Sesuai dengan Pasal 10 Undang-Undang tersebut di atas, ASN memiliki fungsi sebagai: (a) pelaksana kebijakan publik; (b) pelayan publik; dan (c) perekat dan pemersatu bangsa. Guna melaksanakan fungsi tersebut, Pasal 11 Undang-Undang tersebut menyebutkan bahwa ASN (termasuk PNS) memiliki tugas: a) melaksanakan kebijakan publik yang dibuat oleh Pejabat Pembina Kepegawaian sesuai dengan ketentuan peraturan perundang-undangan; (b) memberikan pelayanan publik yang profesional dan berkualitas; dan (c) mempererat persatuan dan kesatuan Negara Kesatuan Republik Indonesia. Dalam rangka mewujudkan PNS yang mampu melaksanakan tugas dan mengemban fungsi tersebut, seseorang yang akan diangkat menjadi PNS harus dididik dan dilatih agar memiliki kualifikasi yang memadai. Pendidikan dan pelatihan merupakan proses yang harus dilalui untuk mengubah dan meningkatkan knowledge, skill, dan attitude pesertanya sehingga memiliki kompetensi dan kualifikasi yang ditetapkan.

Sebagai institusi yang berwenang membuat kebijakan mengenai diklat bagi ASN, Lembaga Administrasi Negara (LAN) telah mengeluarkan Peraturan Kepala LAN Nomor 22 Tahun 2016 Tentang Pedoman Penyelenggaraan Pelatihan Dasar (Latsar) Calon Pegawai Negeri Sipil (CPNS) Golongan I dan Golongan II. Sedangkan untuk mengatur penyelenggaraan Latsar CPNS Golongan III, diterbitkan Peraturan Kepala LAN Nomor 21 Tahun 2016. Sesuai dengan peraturan tersebut, terdapat lima nilai dan materi dasar yang harus diajarkan, yaitu: 1) akuntabilitas, 2) nasionalisme, 3) etika publik, 4) komitmen mutu, dan 5) anti korupsi. Kelima nilai dasar tersebut sering disingkat dengan ANEKA.

Pembukaan Undang-Undang Dasar 1945 menyebutkan bahwa salah satu tujuan nasional adalah mencerdaskan kehidupan bangsa. Sebagai warga negara, PNS berhak untuk menjadi objek "mencerdaskan kehidupan bangsa" yang dilakukan oleh pemerintah, apalagi PNS mengemban tugas untuk melayani masyarakat sesuai dengan fungsi dan tugasnya masing-masing. Pembelajaran nilai dasar ANEKA merupakan upaya untuk meningkatkan ketiga kecerdasan tersebut pada setiap peserta Latsar. 
Pembelajaran nilai dasar ANEKA merupakan upaya perubahan dan pembentukan sikap peserta Latsar agar kelak memiliki sikap dan perilaku sesuai dengan yang diharapkan sebagaimana ditetapkan dalam peraturan perundangan dan sesuai dengan norma yang berlaku.

Penelitian ini bertujuan untuk mengetahui pengaruh pemahaman materi pembelajaran kelima nilai dasar (akuntabilitas, nasionalisme, etika publik, komitmen mutu, dan anti korupsi) terhadap sikap peserta pelatihan dalam mengemban fungsi dan tugas yang diembannya. Dalam hal ini, pemahaman materi diartikan sebagai cara atau proses yang dilakukan sehingga peserta paham terhadap nilai atau materi yang diajarkan. Kelima materi tersebut di atas merupakan nilai-nilai yang diinternalisasikan pada diri peserta dengan harapan dapat mengubah sikap mereka dalam bekerja. Dengan kata lain, penelitian ini hendak membuktikan apakah pemahaman materi pembelajaran kelima nilai dasar tersebut (ANEKA) berpengaruh terhadap sikap peserta Latsar sehingga mampu menjalankan fungsi dan tugas yang diembannya. Sementara itu, sikap yang dimaksudkan dalam penelitian ini adalah pendirian yang dimiliki peserta sehingga mereka siap untuk melaksanakan tugas dan fungsinya. Sikap tersebut lebih merupakan sebagai sikap kerja mereka dalam melaksanakan kebijakan publik, memberikan layanan publik, dan mempererat persatuan/kesatuan bangsa. Selain itu, penelitian ini juga hendak mengetahui pemahaman materi dasar mana yang memberikan pengaruh terbesar terhadap sikap peserta Latsar CPNS. Rumusan masalah yang diangkat dalam penelitian ini adalah: (1) bagaimanakah pengaruh pemahaman materi pembelajaran ANEKA, baik secara bersama-sama (simultan) maupun secara terpisah (parsial), terhadap sikap peserta dalam melaksanakan fungsi/tugas PNS; dan (2) pemahaman nilai dasar manakah yang paling berpengaruh terhadap sikap peserta dalam melaksanakan tugas/fungsi sebagai PNS. Hasil penelitian ini diharapkan dapat menjadi umpan balik terhadap pembelajaran nilai-nilai dasar ANEKA pada Latsar CPNS dan menjadi referensi dalam melakukan koreksi atau pembenahan terhadap pembelajaran Latsar CPNS.

Pendidikan dengan materi penanaman nilai akuntabilitas, nasionalisme, etika publik, komitmen mutu, dan antikorupsi pernah diteliti oleh Raharjo (2016). Dengan objek penelitian CPNS alumni peserta Pelatihan Dasar di Kementerian Keuangan diperoleh kesimpulan bahwa pemahaman materi nilai akuntabilitas, etika publik, komitmen mutu, dan anti korupsi berpengaruh positif terhadap kinerja. Sementara itu, materi nilai nasionalisme memiliki pengaruh negatif terhadap kinerja pegawai.

Adanya pengaruh pemahaman terhadap sikap seorang individu pernah diteliti oleh Faradila, Holilulloh, dan Adha(2014). Dengan populasi siswa SMP Negeri 3 Natar Tahun Pelajaran 2013/2014, penelitian ini menyimpulkan bahwa pemahaman berpengaruh signifkan terhadap pembentukan sikap. Semakin baik pemahaman terhadap ideologi Pancasila maka akan semakin baik juga sikap moral yang dimiliki siswa. Demikian juga sebaliknya, semakin buruk pemahaman terhadap ideologi Pancasila maka semakin buruk pula sikap moralnya. Penelitian Pratiwi (2014) memberikan kesimpulan yang sama dengan penelitian Faradila, Holilulloh, dan Adha(2014). Dalam meneliti pengaruh pemahaman Hak Asasi Manusia terhadap sikap 
kemanusiaan pada siswa kelas VII di SMP Negeri 2 Hulu Sungkai Kabupaten Lampung Utara tahun pelajaran 2012/2013, diperoleh kesimpulan bahwa pemahaman terdapat hubungan yang signifikan antara pemahaman dengan sikap yang dihasilkan. Semakin tinggi tingkat pemahaman siswa mengenai Hak Asasi Manusia, maka semakin tinggi (baik) pula sikap kemanusiaan yang dimilikinya.

Guna mempermudah dalam melakukan penelitian, diperlukan adanya kerangka teori yang akan menjadi gambaran pemikiran mengenai keterkaitan antarvariabel yang diteliti. Dalam penelitian ini, kerangka teori/pemikiran yang disusun adalah sebagaimana terlihat pada Gambar 1.

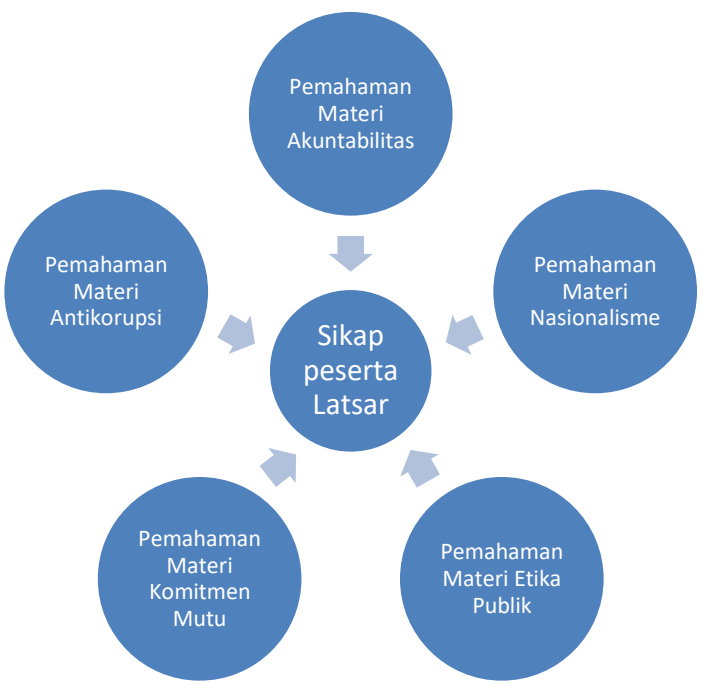

Gambar 1. Kerangka pemikiran

Dari Gambar 1 kerangka pemikiran tersebut, model yang digunakan dalam penelitian ini adalah sebagai berikut:

$$
Y=a+\beta_{1} X_{1}+\beta_{2} X_{2}+\beta_{3} X_{3}+\beta_{4} X_{4}+\beta_{5} X_{5}+e
$$

dimana:

Y

: Sikap peserta Latsar

A : nilai konstanta

$\mathrm{X}_{1} \quad$ : Pemahaman Materi Akuntabilitas

$\mathrm{X}_{2} \quad$ : Pemahaman Materi Nasionalisme

$\mathrm{X}_{3} \quad$ : Pemahaman Materi Etika Publik

$\mathrm{X}_{4} \quad$ : Pemahaman Materi Komitmen Mutu

$\mathrm{X}_{5} \quad$ : Pemahaman Materi Antikorupsi

$\beta_{1}, \beta_{2}, \beta 3, \beta 4$, dan $\beta_{5}$ : koefisien regresi

e : error 
Sesuai dengan tinjauan pustaka dan kerangka pemikiran pada Gambar 1, hipotesis yang hendak diuji dalam penelitian ini adalah:

$\mathrm{H}_{1}$ : Pemahaman materi pembelajaran kelima nilai dasar (akuntabilitas, nasionalisme, etika publik, komitmen mutu, dan anti korupsi) secara simultan memiliki pengaruh yang positif dan signifikan terhadap pembentukan sikap para peserta Latsar.

$\mathrm{H}_{2}$ : Kelima pemahaman materi pembelajaran kelima nilai dasar (akuntabilitas, nasionalisme, etika publik, komitmen mutu, dan anti korupsi) secara parsial masing-masing memiliki pengaruh yang positif dan signifikan terhadap sikap yang terbentuk pada peserta Latsar.

\section{METODE}

Penelitian ini merupakan penelitian kuantitatif, bersifat kausalitas, menganalisis hubungan sebab-akibat antara variabel bebas terhadap variabel terikat. Hal ini sesuai dengan desain diklat yang menjadikan kegiatan diklat sebagai upaya untuk mencapai tujuan yang berupa terbentuknya sikap dan prilaku peserta diklat sesuai dengan yang diharapkan. Adapun pendekatan yang digunakan dalam penelitian ini adalah pendekatan kuantitatif. Sebagai variabel bebas, materi pembelajaran (ANEKA) akan dinilai dalam bentuk score atau angka yang menunjukkan peringkat preferensi yang dimiliki responden. Demikian juga dengan sikap yang diharapkan terbentuk dari materi pembelajaran yang diberikan kepada peserta Latsar. Data yang digunakan dalam studi ini adalah data primer, yakni data yang diperoleh secara langsung dari objek atau populasi yang diteliti. Populasi penelitian adalah para peserta Pelatihan Dasar Periode II tahun anggaran 2018 yang diselenggarakan di Balai Diklat Keuangan Malang yaitu sejumlah 110 orang. Dari populasi tersebut diambil beberapa peserta sebagai sampel penelitian. Jumlah sampel ditentukan dengan teknik random sampling yang dihitung berdasarkan rumus Slovin (Ariola, 2006) yaitu sebanyak 87 orang. Perolehan data dilakukan melalui angket/kuesioner yang disebarkan kepada responden (sampel). Data yang diperoleh selanjutnya didokumentasikan dan diolah dengan teknik statistik.

Dalam penelitian ini terdapat 6 variabel yang digolongkan ke dalam variabel bebas dan terikat. Variabel bebas terdiri atas pemahaman: 1) materi pembelajaran akuntabilitas, 2) materi pembelajaran nasionalisme, 3) materi pembelajaran etika publik, 4) materi pembelajaran komitmen mutu, dan 5) materi pembelajaran antikorupsi. Sementara itu, satu-satunya variabel terikat adalah sikap peserta Latsar setelah mengikuti kelima materi pembelajaran tersebut di atas. Definisi operasional, deskripsi dan indikator masing-masing variabel tersebut dijabarkan pada Tabel 1. Setiap variabel diukur dengan menggunakan skala Likert 5 poin, yaitu sangat setuju: 5 ; setuju: 4 ; kurang setuju: 3 ; tidak setuju: 2 ; sangat tidak setuju: 1. 
Tabel 1. Definisi Operasional, Deskripsi dan Indikator Variabel

\begin{tabular}{|c|c|c|}
\hline Variabel & Deskripsi & Indikator \\
\hline $\begin{array}{l}\text { Pemahaman materi } \\
\text { pembelajaran akuntabilitas. }\end{array}$ & $\begin{array}{l}\text { Adalah adanya pengetahuan dan wawasan } \\
\text { yang dimiliki peserta Latsar sesuai dengan } \\
\text { materi pembelajaran yang diberikan. Hal ini } \\
\text { ditunjukkan dengan tercapainya tujuan } \\
\text { pembelajaran sebagaimana disebutkan dalam } \\
\text { modul mata pelajaran Akuntabilitas. Secara } \\
\text { umum, pemahaman terhadap materi } \\
\text { akuntabilitas adalah adanya pengertian dan } \\
\text { kesadaran bahwa segala segala tindakan } \\
\text { yang dilakukan harus dapat } \\
\text { dipertanggungjawabkan dari berbagai aspek } \\
\text { yang ada. }\end{array}$ & $\begin{array}{l}\text { Variabel ini diukur menggunakan tujuh item } \\
\text { pernyataan, yaitu: } \\
\text { 1. Saya benar-benar memahami nilai-nilai } \\
\text { dasar dan konsep akuntabilitas dalam } \\
\text { pelaksanaan tugas. } \\
\text { 2. Apabila terjadi konflik kepentingan, } \\
\text { saya tetap mematuhi peraturan } \\
\text { perundangan yang berlaku. } \\
\text { 3. Saya sudah memahami tugas dan } \\
\text { pekerjaan yang menjadi tanggung } \\
\text { jawab saya. } \\
\text { 4. Saya harus berkinerja baik dan } \\
\text { maksimal guna mendukung kinerja } \\
\text { organisasi. } \\
\text { 5. Saya menyadari untuk selalu } \\
\text { memberikan layanan yang adil dan } \\
\text { merata kepada pengguna jasa. } \\
\text { 6. Saya senantiasa netral terhadap } \\
\text { kepentingan-kepentingan pihak yang } \\
\text { saya layani. } \\
\text { 7. Saya sudah memahami nilai-nilai } \\
\text { akuntabilitas dan aktualisasinya dalam } \\
\text { tugas/pekerjaan. }\end{array}$ \\
\hline $\begin{array}{l}\text { Pemahaman materi } \\
\text { pembelajaran nasionalisme. }\end{array}$ & $\begin{array}{l}\text { Adalah adanya pengetahuan, informasi, dan } \\
\text { kesadaran pada diri peserta Latsar sehingga } \\
\text { memahami peranan Pancasila dalam } \\
\text { menumbuhkan nasionalisme Aparatur Sipil } \\
\text { Negara (ASN), fungsi dan peran ASN sebagai } \\
\text { Pembuat dan Pelaksana Kebijakan Publik, } \\
\text { peran ASN sebagai Pelayan Publik, dan fungsi } \\
\text { ASN sebagai Perekat dan Pemersatu Bangsa. }\end{array}$ & $\begin{array}{l}\text { Variabel ini diukur menggunakan lima item } \\
\text { pernyataan, yaitu: } \\
\text { 1. Saya benar-benar paham akan } \\
\text { peranan Pancasila dalam } \\
\text { menumbuhkan nasionalisme pada diri } \\
\text { saya. } \\
\text { 2. Sebagai ASN, saya telah paham akan } \\
\text { peran sebagai Pembuat dan Pelaksana } \\
\text { Kebijakan Publik. } \\
\text { 3. Saya telah memahami dan menyadari } \\
\text { peran saya sebagai Pelayan Publik. } \\
\text { 4. Saya telah paham dan sadar untuk } \\
\text { selalu menjadi perekat dan pemersatu } \\
\text { bangsa. } \\
\text { 5. Saya memahami dan menyadari untuk } \\
\text { senantiasa mengimplementasikan nilai- } \\
\text { nilai Pancasila dalam setiap } \\
\text { pelaksanaan tugas. }\end{array}$ \\
\hline $\begin{array}{l}\text { Pemahaman materi } \\
\text { pembelajaran etika publik. }\end{array}$ & $\begin{array}{l}\text { Adalah adanya tambahan pengetahuan, } \\
\text { wawasan, dan informasi pada diri peserta } \\
\text { Latsar mengenai etika publik, khususnya di } \\
\text { lingkungan birokrasi sehingga memiliki } \\
\text { pemahaman tentang kode etik dan perilaku } \\
\text { pejabat publik, mengenali berbagai bentuk } \\
\text { sikap dan perilaku yang bertentangan dengan } \\
\text { kode etik dan perilaku dan implikasi dari } \\
\text { pelanggaran kode etik dan perilaku bagi } \\
\text { dirinya; dan menyadari untuk dapat bersikap } \\
\text { dan berperilaku yang sesuai dengan kode etik } \\
\text { yang berlaku. }\end{array}$ & $\begin{array}{l}\text { Variabel ini diukur menggunakan empat } \\
\text { item pernyataan, yaitu: } \\
\text { 1. Sebagai pegawai/pejabat publik, saya } \\
\text { telah paham terhadap kode etik yang } \\
\text { harus saya pedomani. } \\
\text { 2. Saya telah mengetahui berbagai sikap } \\
\text { dan perilaku yang bertentangan } \\
\text { dengan kode etik. } \\
\text { 3. Saya telah mengetahui dan menyadari } \\
\text { implikasi/akibat yang saya terima } \\
\text { apabila melanggar kode etik dan norma } \\
\text { yang berlaku } \\
\text { 4. Saya senantiasa sadar untuk bersikap } \\
\text { dan berperilaku sesuai dengan kode } \\
\text { etik dan norma yang berlaku. }\end{array}$ \\
\hline
\end{tabular}


Achmat Subekan, Azwar Iskandar - Pengaruh Pemahaman Nilai Dasar 'Aneka' Terhadap Pembentukan Sikap Peserta Latsar CPNS pada Balai Diklat Keuangan Malang

「abel 1. Lanjutan

\begin{tabular}{ll}
\hline \multicolumn{1}{c}{ Variabel } & \multicolumn{1}{c}{ Deskripsi } \\
\hline $\begin{array}{l}\text { Pemahaman materi } \\
\text { pembelajaran komitmen }\end{array}$ & Adalah adanya tambahan pengetahuan, \\
mutu. & wawasan, informasi, dan kesadaran pada \\
& diri peserta Latsar sehingga mampu \\
& mengidentifikasi da mendeskripsikan \\
& fenomena empirik terkait efektivitas dan \\
& efisiensi kinerja PNS di lingkungan kerja, \\
& mendeskripsikan karakteristik ideal dari \\
& tindakan yang efektif, efisien, inovatif, dan \\
& berorientasi mutu dalam penyelenggaraan \\
& pemerintahan dan pelayanan publik, dan \\
& mampu memberikan contoh nyata \\
& pemberian layanan publik yang efektif, \\
& efisien, inovatif, dan berorientasi mutu.
\end{tabular}

Pemahaman materi pembelajaran antikorupsi.

Sikap peserta Latsar
Adalah adanya tambahan pengetahuan, wawasan, informasi, dan kesadaran pada diri peserta Latsar sehingga mampu menjelaskan berbagai dampak dar perilaku dan tindak pidana korupsi, memahami pengertian korupsi, mengenali delik-delik tindak pidana korupsi yang berlaku di Indonesia, memiliki niat, semangat, dan komitmen melakukan pemberantasan korupsi, dan membuat impian Indonesia yang bebas dari korupsi.

Adalah perbuatan dan sebagainya yang didasarkan pada pendirian dan keyakinan. Dengan demikian, sikap adalah pendirian dan keyakinan yang diperoleh dari adanya pengertian yang mendalam terhadap materi pembelajaran ANEKA dan menjadi dasar bagi lahirnya prilaku positif pada diri peserta Latsar. Prilaku positif tersebut ditunjukkan dengan pelaksanaan tugas dan fungsi yang harus diemban oleh peserta Latsar sebagai PNS, yaitu: 1) pelaksana kebijakan publik, 2) pemberi layanan publik, dan 3) perekat persatuan bangsa.

\section{Indikator}

Variabel ini diukur menggunakan tujuh item pernyataan, yaitu:

1. Saya mampu mengidentifikasi dan mendeskripsikan fenomena empirik efektivitas dan efisiensi kinerja saya di tempat tugas.

2. Saya mampu mendeskripsikan karakteristik ideal dari tindakan yang efektif, efisien, inovatif, dan berorientasi mutu dalam melaksanakan tugas.

3. Saya sudah mampu memberikan contoh nyata pemberian layanan publik yang efektif, efisien, inovatif, dan berorientasi mutu.

4. Saya telah paham akan konsekuensi penyelenggaraan kerja yang tidak efektif dan tidak efisien.

5. Saya mampu mengidentifikasi dan mendeskripsikan nilai-nilai dasar orientasi mutu.

6. Saya sudah dapat mendeskripsikan implementasi pendekatan inovatif dalam penyelenggaraan tugas.

7. Saya mampu menganalisis berbagai upaya untuk meningkatkan produktivitas kerja saya.

Variabel ini diukur menggunakan empat item pernyataan, yaitu:

1. Saya mampu menjelaskan berbagai dampak dari perilaku dan tindak pidana korupsi.

2. Saya telah memahami pengertian korupsi yang dimaksudkan dalam peraturan perundangan

3. Saya mampu mengenali delik-delik tindak pidana korupsi yang berlaku di Indonesia.

4. Saya telah memiliki niat, semangat, dan komitmen melakukan pemberantasan korupsi.

5. Saya bertekad bulat untuk mewujudkan Indonesia yang bebas dari korupsi.

Variabel ini diukur menggunakan 10 item pernyataan, yaitu:

1. Saya sangat sadar akan tugas saya sebagai pelaksana kebijakan publik.

2. Saya dapat memahami kebijakan publik yang diambil oleh institusi tempat saya bekerja.

3. Saya mampu mempertanggungjawabkan tugas dan pekerjaan saya sesuai dengan peraturan perundangan yang berlaku.

4. Saya menempatkan kepuasan pengguna jasa sebagai prioritas utama layanan yang saya berikan 
「abel 1. Lanjutan

\begin{tabular}{|c|c|c|}
\hline Variabel & Deskripsi & Indikator \\
\hline & & $\begin{array}{l}\text { 5. Saya akan selalu bersedia melayani } \\
\text { pengguna jasa walaupun bukan tugas } \\
\text { utama saya. } \\
\text { 6. Saya akan menerima dengan terbuka } \\
\text { protes, keluhan, dan ketidakpuasan } \\
\text { pengguna jasa serta menjadikannya } \\
\text { sebagai masukan perbaikan diri. } \\
\text { 7. Saya selalu siap dan sukarela } \\
\text { ditempatkan di mana pun untuk } \\
\text { mengemban tugas negara. } \\
\text { 8. Saya akan selalu berteman/berkawan } \\
\text { baik dengan orang dan masyarakat } \\
\text { tempat saya berada. } \\
\text { 9. Saya akan senantiasa mendamaikan } \\
\text { orang/masyarakat yang sedang } \\
\text { berselisih. } \\
\text { 10. Dalam memilih teman/kawan, saya } \\
\text { tidak akan membeda-bedakan latar } \\
\text { belakang suku, budaya, dan latar } \\
\text { belakang sosial lannya. }\end{array}$ \\
\hline
\end{tabular}

Teknik analisis data penelitian menggunakan teknik Regresi Linier Berganda. Nachrowi dan Usman (2006) menjelaskan bahwa salah satu teknik analisis kuantitatif yang dapat memberikan informasi mengenai hubungan dua variabel adalah teknik permodelan regresi linier. Pemodelan regresi liner yang cukup populer adalah regresi linier sederhana (simple regression) dan regresi linier majemuk (multiple regression). Analisis ini juga disebut dengan metode simpangan kuadrat terkecil biasa (Ordinary Least Square $=\mathrm{OLS}$ ) yang merupakan metode pendugaan dengan meminimumkan jumlah kuadrat simpangan dari hasil pendugaan atau estimasi variabel tak bebas. Prosedur ini digunakan untuk mendapatkan hasil pendugaan parameter yang memiliki sifat tak bias linier terbaik (Bias Linier Unbiased Estimator = BLUE). Secara singkat BLUE mengandung arti bahwa pendugaan parameter yang dihasilkan akan memiliki varian yang minimum dan tidak berarti pendugaan dari masing-masing sampel akan sama populasinya. Untuk memperoleh kesimpulan apakah model yang digunakan memiliki kelayakan untuk menjelaskan hubungan antara variabel dependen dan variabel independen, maka model akan melalui beberapa pengujian. Pengujian tersebut meliputi pengujian atas asumsi yang digunakan dan pengujian statistik terhadap model atau fungsi regresi yang dihasilkan (Nachrowi dan Usman, 2006).

Uji asumsi klasik merupakan prasyarat analisis regresi ganda. Dalam uji asumsi klasik ini meliputi uji normalitas dan uji multikolinieritas. Uji normalitas adalah pengujian tentang kenormalan distribusi data. Penggunaan uji normalitas karena pada analisis statistik parametik, asumsi yang harus dimiliki oleh data adalah bahwa data tersebut harus terdistribusi secara normal. Maksud data terdistribusi secara normal adalah bahwa data akan mengikuti bentuk distribusi normal (Santosa dkk., 2002). Pada penelitian ini penulis melakukan uji normalitas dengan Tabel Kolmogorov Smirnov. Dengan melihat nilai Asymp. Sig. (2-tailed), bila nilai tiap variabel lebih dari 0,05 $(>0,05)$ maka uji normalitas terpenuhi atau data telah terdistribusi normal (Santoso, dkk, 2002). 
Sedangkan uji multikolinieritas bertujuan untuk menguji apakah model regresi ditemukan adanya korelasi antarvariabel bebas (independen). Model regresi yang baik seharusnya tidak terjadi korelasi di antara variabel independen. Jika variabel independen saling berkorelasi, maka variabel-variabel ini tidak ortogonal (Ghozali, 2006). Untuk mendeteksi adanya multikolinearitas, dapat dilihat dari nilai tolerance atau uji Value Inflation Factor (VIF). Apabila nilai tolerance value lebih tinggi daripada 0,10 atau VIF lebih kecil daripada 10 maka dapat disimpulkan tidak terjadi multikolinearitas (Santoso, dkk., 2002).

\section{Instrumen Penelitian}

Sebelum melakukan analisis terhadap data, terlebih dahulu dilakukan uji kualitas data. Pengujian kualitas data bertujuan untuk mengetahui apakah instrumen yang digunakan valid dan reliable, sebab kebenaran data yang diolah sangat menentukan kualitas hasil penelitian. Uji kualitas data yang digunakan dalam penelitian ini adalah uji validitas dan realibilitas.

1. Uji Validitas adalah suatu ukuran yang menunjukkan tingkat kevalidan atau kesahihan suatu instrumen (Arikunto, 2008). Suatu kuesioner dikatakan valid jika pertanyaan pada kuesioner mampu untuk mengungkapkan sesuatu yang akan diukur oleh kuesioner tersebut. Uji signifikansi dilakukan dengan cara membandingkan nilai $r$ hitung dengan $r$ tabel untuk degree of freedom (df) $=n-2$, dalam hal ini $n$ adalah jumlah sampel. Untuk menguji apakah masing-masing indikator valid atau tidak, dapat dilihat dalam tampilan output Cronbach Alpha pada kolom Correlated Item-Total Correlation. Jika $r$ hitung lebih besar dari $r$ tabel dan nilai positif maka butir atau pertanyaan atau indikator tersebut dinyatakan valid.

2. Uji Reliabilitas, menurut Ghozali (2006), adalah alat untuk mengukur suatu kuesioner yang merupakan indikator dari variabel atau konstruk. Suatu kuesioner dikatakan reliabel atau handal jika jawaban seseorang terhadap pernyataan adalah konsisten atau stabil dari waktu ke waktu. Pengukuran reliabilitas dapat dilakukan dengan dua cara yaitu: (i) repated measure atau pengukuran ulang: di sini objek penelitan akan disodori soal yang sama pada waktu yang berbeda, dan kemudian dilihat apakah jawabannya sama atau tidak; (ii) one shot atau pengukuran sekali saja: di sini pengukurannya hanya sekali dan kemudian hasilnya dibandingkan dengan pertanyaan lain atau mengukur korelasi antar jawaban pertanyaan. Software SPSS menyediakan fasilitas ini dengan uji statistik Cronbach Alpha (a). Uji reliabilitas dengan menggunakan metode Cronbach Alpha (a) diukur berdasarkan skala Cronbach Alpha (a) 0 sampai 1. Nilai Cronbach Alpha $\geq 0,5$ dikategorikan reliable (Triton, 2005).

Uji Validitas ditujukan untuk mengetahui validitas pertanyaan-pertanyaan yang disajikan dalam kuesioner. Pengujian ini menghasilkan kesimpulan bahwa pertanyaan dalam instrumen penelitian yang dibuat adalah valid, yaitu lolos uji validitas. Hal ini 
ditunjukkan dengan hasil korelasi antara setiap butir pertanyaan (item) dengan total skor variabel yang bersangkutan. Hasil pengujian sebagaimana Tabel 2.

Tabel 2. Hasil Uji Validitas

\begin{tabular}{|c|c|c|c|}
\hline Variabel & $\begin{array}{c}\text { Item } \\
\text { Pernyataan }\end{array}$ & $\begin{array}{l}\text { Corrected Item- } \\
\text { Total Correlation }\end{array}$ & $\begin{array}{c}r \text {-tabel, } \\
(\mathrm{df})=\mathrm{N}-2=81\end{array}$ \\
\hline \multirow{7}{*}{$X_{1}$} & 1 & $0,574^{* *}$ & \\
\hline & 2 & $0,575^{\star *}$ & \\
\hline & 3 & $0,507^{* *}$ & \\
\hline & 4 & $0,543^{* *}$ & \\
\hline & 5 & $0,573^{* *}$ & \\
\hline & 6 & $0,586^{* *}$ & \\
\hline & 7 & $0,617^{\text {** }}$ & \\
\hline \multirow{5}{*}{$X_{2}$} & 1 & $0,672^{* *}$ & \\
\hline & 2 & $0,726^{* *}$ & \\
\hline & 3 & $0,688^{* *}$ & \\
\hline & 4 & $0,608^{* *}$ & \\
\hline & 5 & $0,659^{* *}$ & \\
\hline \multirow{4}{*}{$X_{3}$} & 1 & $0,771^{* *}$ & \\
\hline & 2 & $0,694^{* *}$ & \\
\hline & 3 & $0,780^{* *}$ & \\
\hline & 4 & $0,669^{* *}$ & \\
\hline \multirow{7}{*}{$X_{4}$} & 1 & $0,669^{* *}$ & \\
\hline & 2 & $0,773^{* *}$ & \\
\hline & 3 & $0,787^{* *}$ & \\
\hline & 4 & $0,610^{* *}$ & \\
\hline & 5 & $0,700^{* *}$ & \\
\hline & 6 & $0,796^{* *}$ & \\
\hline & 7 & $0,737^{* *}$ & \\
\hline \multirow{5}{*}{$X_{5}$} & 1 & $0,674^{* *}$ & \\
\hline & 2 & $0,750^{* *}$ & \\
\hline & 3 & $0,696^{* *}$ & \\
\hline & 4 & $0,771^{* *}$ & \\
\hline & 5 & $0,550^{* *}$ & \\
\hline \multirow{10}{*}{ Y } & 1 & $0,625^{* *}$ & \\
\hline & 2 & $0,714^{* *}$ & \\
\hline & 3 & $0,626^{* *}$ & \\
\hline & 4 & $0,438^{* *}$ & \\
\hline & 5 & $0,529^{* *}$ & \\
\hline & 6 & $0,610^{* *}$ & \\
\hline & 7 & $0,601^{* *}$ & \\
\hline & 8 & $0,599^{* *}$ & \\
\hline & 9 & $0,638^{* *}$ & \\
\hline & 10 & $0,546^{* *}$ & \\
\hline
\end{tabular}

${ }^{* *}$. Correlation is significant at the 0,01 level (2-tailed).

*. Correlation is significant at the 0,05 level (2-tailed).

Sumber: Data primer (diolah)

Catatan:

$\mathrm{X}_{1}$ : Pemahaman Materi Akuntabilitas

$\mathrm{X}_{4}:$ Pemahaman Materi Komitmen Mutu

$\mathrm{X}_{2}$ : Pemahaman Materi Nasionalisme

$X_{5}$ : Pemahaman Materi Antikorupsi

$\mathrm{X}_{3}$ : Pemahaman Materi Etika Publik

$Y$ : Sikap peserta Latsar 
Berdasarkan Tabel 2, dengan membandingkan masing-masing nilai $r$-hitung (Correlation Item-Total Correlation) pada setiap item pertanyaan berdasarkan Tabel 2 dengan $r$-tabel untuk degree of freedom $(\mathrm{df})=\mathrm{N}-2=$ dan alpha $5 \%$, di mana $r$-tabel $=$ 0,2159 , maka dapat dinyatakan bahwa semua nilai $r$-hitung masing-masing pertanyaan yang digunakan sebagai instrumen untuk mengukur vaiabel penelitian adalah lebih besar dari nilai $r$-tabel. Sehingga dapat dinyatakan bahwa seluruh item pertanyaan pada instrumen penelitian (kuesioner) adalah valid.

Selanjutnya, reliabilitas instrumen diketahui dari nilai Cronbach's Alpha hasil pengolahan data. Apabila nilai Cronbach's Alpha berada di atas 0,5 maka instrumen dinyatakan reliabel. Sedangkan apabila kurang dari angka tersebut maka instrumen dinyatakan tidak reliabel. Hasil pengolahan data yang telah dilakukan adalah sebagaimana Tabel 3.

Tabel 3. Hasil Uji Reliabilitas

\begin{tabular}{ccc}
\hline Variabel & Cronbach's Alpha & Nof ltems \\
\hline$X_{1}$ & 0,642 & 7 \\
$X_{2}$ & 0,696 & 5 \\
$X_{3}$ & 0,752 & 4 \\
$X_{4}$ & 0,848 & 7 \\
$X_{5}$ & 0,714 & 5 \\
$Y$ & 0,793 & 10 \\
\hline
\end{tabular}

Sumber: Data primer (diolah)

Berdasarkan Tabel 3, dengan membandingkan nilai Cronbach Alpha instrumen penelitian dengan nilai kriteria realibilitas sebagaimana yang disebutkan oleh Triton (2005), maka dapat dinyatakan bahwa instrumen penelitian untuk seluruh variabel adalah reliable yaitu berada nilai Cronbach Alpha yang melebihi nilai ambang batas. Hal ini berarti semua butir pernyataan mempunyai kehandalan/konsistensi yang dapat dipertanggungjawabkan (reliable).

\section{Uji hipotesis penelitian}

1. Uji statistik $t$ (Secara Parsial). Menurut Imam Ghozali (2006) uji statistik $t$ pada dasarnya menunjukkan seberapa jauh pengaruh satu variabel independen secara individual dalam menerangkan variabel dependen. Pengujian dilakukan dengan menggunakan signifikan level $0,05(\alpha=5 \%)$. Penerimaan atau penolakan hipotesis dilakukan dengan kriteria:

a. Jika nilai signifikan (Sig.) $>0,05$ atau thitung $<t_{\text {tabel }}$ (nilai minus diabaikan) maka hipotesis ditolak atau koefisien regresi tidak signifikan. Ini berarti secara parsial variabel independen tidak mempunyai pengaruh secara signifikan terhadap variabel dependen.

b. Jika nilai signifikan (Sig.) $\leq 0,05$ atau thitung $>t_{\text {tabel }}$ (nilai minus diabaikan) maka hipotesis diterima atau koefisien regresi signifikan. Ini berarti secara 
Achmat Subekan, Azwar Iskandar - Pengaruh Pemahaman

Nilai Dasar 'Aneka' Terhadap Pembentukan Sikap Peserta

Latsar CPNS pada Balai Diklat Keuangan Malang

parsial variabel independen tersebut mempunyai pengaruh yang signifikan terhadap variabel dependen.

2. Uji Statistik $F$ (Secara Simultan). Menurut Imam Ghozali (2006) Uji statistik F pada dasarnya menunjukkan apakah semua variabel bebas yang dimasukkan dalam model mempunyai pengaruh signifikan secara bersama-sama (simultan) terhadap variabel terikat. Kriteria pengujian dimana hipotesis diterima apabila nilai ANOVA $F_{\text {hitung }}>F_{\text {tabel }}$ atau nilai Sig. $<\alpha$. Dalam hal ini $\alpha=0,05$.

\section{HASIL DAN PEMBAHASAN}

\section{Gambaran Responden}

Responden penelitian adalah para peserta Pelatihan Dasar (Latsar) CPNS Golongan II Periode II tahun anggaran 2018 yang diselenggarakan di Balai Diklat Keuangan Malang. Mereka berjumlah 87 orang dan berasal dari berbagai kantor Kementerian Keuangan di Provinsi Jawa Timur. Data penelitian diambil melalui kuesioner yang telah disiapkan pada saat mereka melakukan ujian presentasi hasil aktualisasi. Dengan demikian, pengambilan data dilakukan pada ujung waktu pelaksanaan pelatihan dimana peserta telah melaksanakan aktualisasi yang telah dijadwalkan. Dengan waktu pengambilan data yang demikian, diharapkan peserta telah merasakan ada atau tidaknya pengaruh dari materi pembelajaran yang mereka peroleh terhadap sikap yang mereka miliki. Kuesioner diberikan secara langsung kepada semua responden. Dari sejumlah kuesioner yang diberikan kepada responden, terdapat 83 kuesioner yang dikembalikan oleh responden (response rate sebesar 95,04\%). Jumlah ini dianggap sangat memadai karena memiliki selisih yang sedikit dari jumlah responden yang ditargetkan, yaitu 87 orang responden. Kuesioner yang telah diisi oleh responden selanjutnya direkap dan diolah sebagaimana metode pengolahan data yang telah diuraikan.

Dari hasil rekapiltulasi data, diketahui bahwa jumlah responden laki-laki ada sebanyak 36 orang peserta (43,37\%), sedangkan responden perempuan sebanyak 47 orang peserta $(56,63 \%)$. Semua berstatus belum menikah. Dari sisi usia diperoleh gambaran bahwa responden relatif seusia. Mereka memiliki usia antara 18 tahun sampai dengan 22 tahun. Rata-rata usia mereka adalah 20 tahun 6 bulan. Kondisi usia yang hampir sama tersebut dikarenakan mereka adalah alumni Program Diploma I dan Program Diploma III PKN-STAN. Setelah lulus dari SMA mereka diterima di PKN STAN guna menempuh pendidikan Diploma I dan Diploma III. Lulus dari pendidikan kedinasan tersebut, mereka pun segera diangkat menjadi CPNS dan selanjutnya diikutsertakan dalam Pelatihan Dasar CPNS. Umur mereka yang relatif sama dan masih muda menunjukkan bahwa mereka memiliki psikologi yang hampir sama yang secara umum mereka masih sangat membutuhkan bimbingan dari pihak lain yang lebih senior. Sementara itu, perbedaan asal kantor (Direktorat Jenderal Pajak dan Direktorat Jenderal Bea dan Cukai) tidak terlalu memberikan pengaruh dalam mereka memberikan jawaban kuesioner. Walaupun berbeda unit eselon I, mereka tetap berada dalam Kementerian Keuangan yang mengembankan nilai-nilai yang sama. Kementerian ini menanamkan dan mengembangkan nilai integritas, profesionalisme, 
sinergi, pelayanan, dan kesempurnaan bagi seluruh pegawainya. Dengan demikian, budaya kerja yang mereka miliki juga tidak banyak mengalami perbedaan.

\section{Uji Asumsi Klasik}

Uji asumsi klasik dimaksudkan untuk mengetahui model penelitian yang dibangun, apakah dapat digunakan untuk menggambarkan hubungan antarvariabel yang diteliti. Uji ini mencakup beberapa macam pengujian, yaitu:

\section{a. Uji Normalitas}

Pengujian ini dimaksudkan untuk mengetahui apakah data penelitian yang diperoleh memiliki distribusi yang normal ataukah tidak. Apabila memiliki distribusi yang normal, maka data penelitian tersebut layak dan mampu menggambarkan objek penelitian dengan baik. Hasil pengolahan data menunjukkan bahwa data penelitian memiliki distribusi yang normal. Hal ini ditunjukkan oleh hasil pengolahan data sebagaimana Tabel 4.

Tabel 4. Hasil Uji Normalitas

\begin{tabular}{lccc}
\hline & \multicolumn{3}{c}{ Kolmogorov-Smirnov } \\
\cline { 2 - 4 } & Statistic & df & Sig. \\
\hline Standardized Residual & 0,049 & 83 & $0,200^{*}$ \\
\hline Sumber: Data primer (diolah) & & &
\end{tabular}

Nilai signifikan yang tertera pada Tabel 4 adalah 0,200. Angka tersebut berada di atas nilai alpha yang ditetapkan, yaitu 0,05 . Dengan demikian, data penelitian yang diperoleh memiliki distribusi yang normal.

\section{b. Uji Multikolinieritas}

Pengujian ini digunakan untuk mengetahui adanya korelasi antarvariabel bebas. Korelasi antarvariabel bebes tersebut dianggap akan mengganggu korelasi antara variabel bebas bersangkutan dengan variabel terikat. Hasil pengolahan data menunjukkan bahwa antarvariabel bebas memiliki korelasi. Hal ini ditunjukkan sebagaimana Tabel 5.

Tabel 5. Hasil Uji Multikolinieritas

\begin{tabular}{|c|c|c|c|}
\hline \multicolumn{4}{|c|}{ Coefficients $^{a}$} \\
\hline \multirow{2}{*}{\multicolumn{2}{|c|}{ Model }} & \multicolumn{2}{|c|}{ Collinearity Statistics } \\
\hline & & Tolerance & VIF \\
\hline \multirow[t]{5}{*}{1} & $X_{1}$ & 0,484 & 2,067 \\
\hline & $X_{2}$ & 0,557 & 1,794 \\
\hline & $X_{3}$ & 0,487 & 2,052 \\
\hline & $X_{4}$ & 0,526 & 1,901 \\
\hline & $X_{5}$ & 0,477 & 2,097 \\
\hline
\end{tabular}

Sumber: Data primer (diolah) 
Catatan:

$\mathrm{X}_{1}$ : Pemahaman Materi Akuntabilitas

$X_{2}$ : Pemahaman Materi Nasionalisme

$X_{3}$ : Pemahaman Materi Etika Publik

$\mathrm{X}_{4}$ : Pemahaman Materi Komitmen Mutu

$X_{5}$ : Pemahaman Materi Antikorupsi

Dari Tabel 5 dapat diketahui bahwa antarvariabel bebas tidak mengalami gejala multikolinieritas dengan perolehan nilai tolerance value lebih tinggi daripada 0,10 atau VIF lebih kecil daripada 10.

\section{Regresi Simultan Variabel Bebas Terhadap Variabel Terikat}

Regresi ini dimaksudkan untuk mengetahui pengaruh kelima variabel bebas terhadap variabel terikat secara bersama-sama (simultan). Hasil pengolahan data ditunjukkan dengan Tabel 6.

Tabel 6. Hasil Uji Regresi Simultan

\begin{tabular}{llccccc}
\hline Model & & Sum of Squares & df & Mean Square & F & Sig. \\
\hline \multirow{2}{*}{1} & Regression & 5,512 & 5 & 1,102 & 35,634 & $0,000^{\mathrm{b}}$ \\
& Residual & 2,382 & 77 & 0,031 & & \\
\cline { 2 - 6 } & Total & 7,895 & 82 & & & \\
\hline
\end{tabular}

a. Dependent Variabel: y

b. Predictors: (Constant), x5, x2, x4, x3, x1

Sumber: Data primer (diolah)

Dari Tabel 6 dapat diketahui bahwa nilai Sig. yang dihasilkan adalah 0,000. Angka ini menunjukkan bahwa kelima variabel bebas secara simultan memberikan pengaruh yang signifikan terhadap variabel terikat. Bahkan angka signifikansi ini sudah berada pada angka yang terkuat, yakni terendah. Apabila dilihat dari perbandingan antara $F$-hitung $(35,534)$ dan $F$-table $(2,33)$, maka nilai $F$ hitung memiliki nilai yang lebih besar. Hal ini juga menunjukkan bahwa secara simultan kelima variabel bebas memberikan pengaruh yang signifikan terhadap variabel terikat. Dengan demikian, kelima variabel bebas memiliki keterkaitan kuat sehingga perlu dipertimbangkan lebih dalam apabila ingin mencabut salah satunya. Demi menjaga signifikansi pengaruh kelimanya terhadap pembentukan dan penguatan sikap peserta Latsar, maka sebaiknya kelima materi utama Latsar tersebut tetap dipertahankan. Dengan pembuktian ini, dapat dinyatakan bahwa hipotesis pertama $\left(\mathrm{H}_{1}\right)$ penelitian ini diterima.

\section{Regresi Parsial Variabel Bebas Terhadap Variabel Terikat}

Hubungan atau pengaruh variabel bebas terhadap variabel terikat bisa jadi memiliki kekuatan yang berbeda-beda. Hal ini dapat diketahui dari nilai koefisien yang diperoleh dari hasil pengolahan data. Demikian juga dengan signifikan tidaknya hubungan pengaruh variabel bebas terhadap variabel terikat. Hasil pengolahan data 
mengenai regresi antara variabel bebas dan variabel terikat dalam penelitian ini adalah sebagaimana Tabel 7.

Tabel 7. Hasil Uji Koefisien Regresi Parsial

\begin{tabular}{|c|c|c|c|c|c|c|}
\hline & \multirow[t]{2}{*}{ Model } & \multicolumn{2}{|c|}{ Unstandardized Coefficients } & \multirow{2}{*}{$\begin{array}{c}\text { Standardized } \\
\text { Coefficients } \\
\text { Beta }\end{array}$} & \multirow[t]{2}{*}{$t$} & \multirow[t]{2}{*}{ Sig. } \\
\hline & & $\mathrm{B}$ & Std. Error & & & \\
\hline \multirow{6}{*}{1} & (Constant) & 1,070 & 0,328 & & 3,264 & 0,002 \\
\hline & $X_{1}$ & $-0,089$ & 0,097 & $-0,082$ & $-0,916$ & 0,363 \\
\hline & $X_{2}$ & 0,184 & 0,075 & 0,206 & 2,463 & 0,016 \\
\hline & $X_{3}$ & 0185 & 0,066 & 0,252 & 2,815 & 0,006 \\
\hline & $X_{4}$ & 0,274 & 0,064 & 0,368 & 4,269 & 0,000 \\
\hline & $X_{5}$ & 0,225 & 0,081 & 0,253 & 2,785 & 0,007 \\
\hline
\end{tabular}

a. Dependent Variable: $Y$

Sumber: Data primer (diolah)

Catatan:

$\mathrm{X}_{1}$ : Pemahaman Materi Akuntabilitas

$\mathrm{X}_{2}$ : Pemahaman Materi Nasionalisme

$\mathrm{X}_{3}$ : Pemahaman Materi Etika Publik

$\mathrm{X}_{4}$ : Pemahaman Materi Komitmen Mutu

$\mathrm{X}_{5}$ : Pemahaman Materi Antikorupsi

Dari Tabel 7 dapat diketahui bahwa nilai konstanta yang dihasilkan adalah 1,070. Sementara itu, nilai koefisien untuk X1 adalah $-0,089$, nilai koefisien untuk X2 adalah 0,184 , nilai koefisien untuk $X 3$ adalah 0,185 , nilai koefisien untuk $X 4$ adalah 0,274 , dan nilai koefisien untuk $X 5$ adalah 0,225 . Adapun signifikan tidaknya nilai koefisien yang dihasilkan tersebut dapat diketahui dengan melihat nilai sig. pada setiap variabel bebas tersebut. Nilai sig. X1 sampai dengan X5 berturut adalah 0,363; 0,016; 0,$006 ; 0,000$; dan 0,007. Kelima nilai sig. tersebut dibandingkan dengan nilai alpha yang ditetapkan, yaitu 0,05 . Apabila nilai sig. lebih besar dari 0,05 maka pengaruh variabel bebas berkenaan terhadap variabel terikat adalah tidak signifikan. Sebaliknya, apabila nilai sig. lebih kecil dari 0,05 maka pengaruh variabel bebas berkenaan terhadap variabel terikat adalah signifikan.

Dari kelima variabel bebas di atas, variabel X1 memiliki hubungan/pengaruh yang tidak signifikan karena nilai sig-nya adalah 0,363 (di atas 0,05 ). Tidak adanya pengaruh pemahaman akuntabilitas terhadap sikap peserta dalam bekerja disebabkan oleh adanya penanaman nilai akuntabilitas sejak mereka menempuh pendidikan/kuliah Diploma Keuangan. Sejak kuliah mereka telah mendapatkan mata kuliah yang disusun berdasarkan peraturan perundangan yang berlaku. Di samping itu, pada setiap posisi 
Achmat Subekan, Azwar Iskandar - Pengaruh Pemahaman

Nilai Dasar 'Aneka' Terhadap Pembentukan Sikap Peserta

Latsar CPNS pada Balai Diklat Keuangan Malang

(job) yang mereka tempati selalu ada Standar Operasional dan Prosedur (SOP) yang harus mereka taati. Sebagai bagian dari Kementerian Keuangan, kantor tempat mereka bekerja juga harus melaksanakan Peraturan Menteri Keuangan Nomor 103/PMK.09/2010 Tentang Tata Cara Tindak Lanjut Pelaporan Pelanggaran (whistleblowing) di Lingkungan Kementerian Keuangan. Implementasi sistem whistleblowing ini merupakan salah satu bentuk internal control dalam pelaksanaan pelayanan pubik. Shaoul, et al., (2012) dalam penelitiannya menemukan bahwa faktor internal control dapat mendorong terciptanya akuntabilitas yang baik pada sektor publik. Faktor-faktor tersebut telah mendorong mereka memiliki kesadaran terhadap nilai akuntabilitas dalam bekerja sehingga materi akuntabilitas yang diberikan saat mengikuti Latsar tidak berpengaruh signifikan.

Sedangkan untuk variabel bebas yang lain memiliki pengaruh yang signifikan terhadap variabel terikat. Dalam kajian teori, akuntabilitas kerap dihubungkan dengan praktek good governance yang berimplikasi terhadap pelayanan publik, pengelolaan keuangan negara dan jaminan pemenuhan hak-hak warga negara yang mendasar, dari perilaku penyimpangan dan korupsi serta pelanggaran hokum (Bhuiyan \& Amagoh, 2011; Morrell, 2009; United Nation Human Rights, 2012). Dengan pembuktian ini, dapat dinyatakan bahwa hipotesis kedua $\left(\mathrm{H}_{2}\right)$ penelitian ini ditolak.

Dengan merujuk pada model penelitian yang digunakan dan memperhatikan hasil pengolahan data tersebut, maka model penelitian yang dihasilkan adalah:

$$
Y=1,070-0,089 X_{1}+0,184 X_{2}+0,185 X_{3}+0,274 X_{4}+0,225 X_{5}+e
$$

Berdasarkan model penelitian yang dihasilkan tersebut di atas, dapat dijelaskan beberapa hal di bawah ini:

1. Peserta Latsar telah memiliki nilai-nilai, prinsip, pemahaman, ataupun disebut dengan nama yang lain yang memengaruhi sikap mereka. Hal ini ditunjukkan dengan adanya nilai konstanta sebesar 1,070. Tanpa adanya faktor X1 sampai dengan $\mathrm{X} 5$, sikap peserta Latsar telah terbentuk dengan nilai konstanta sebesar angka tersebut di atas. Hal ini menunjukkan bahwa peserta Latsar datang mengikuti pelatihan tidak dengan modal kosong. Mereka telah memiliki sesuatu yang menuntunnya dalam bersikap terhadap sesuatu. Hal tersebut bisa berupa pemahaman agama, pengetahuan selama menempuh pendidikan, pengalaman selama bekerja, dan pengalaman lain yang mereka peroleh selama berinteraksi dengan orang lain.

2. Pemahaman peserta Latsar terhadap mata pelajaran akuntabilitas (X1) yang disampaikan selama Latsar tidak memberikan pengaruh terhadap sikap mereka. Hal ini ditunjukkan dengan nilai koefisien untuk variabel ini sebesar -0,089 dengan nilai alpha 0,363 yang berarti pemahaman materi akuntabilitas tidak memberikan pengaruh signifikan terhadap sikap (Y) yang dimiliki peserta Latsar. Apabila dicermati, substansi mata pelajaran akuntabilitas telah tercakup dalam mata-mata pelajaran lainnya (nasionalisme, etika publik, komitmen mutu, dan antikorupsi). Akuntabilitas seorang pegawai akan muncul seiring dengan menguatnya 
nasionalisme yang mereka miliki, etika publik yang mereka miliki, semangat mereka untuk terus meningkatkan pelayanan, dan semakin sadarnya mereka untuk ikut serta dalam pemberantasan korupsi. Penerapan standar operasional dan prosedur (SOP), whistleblowing system dan pengenaan sanksi yang tegas apabila melakukan pelanggaran telah mendorong mereka untuk akuntabel dalam setiap pekerjaan yang dilaksanakannya.

3. Mata pelajaran nasionalisme (X2) memberikan pengaruh yang positif terhadap sikap yang dimiliki peserta Latsar. Hal ini ditandai dengan nilai koefisien untuk materi ini sebesar 0,184 . Nilai koefisien yang positif berarti semakin bertambahnya pemahaman peserta akan mata pelajaran nasionalisme akan semakin memperkuat sikap positif yang kelak dimiliki peserta Latsar. Pengaruh positif ini dibarengi dengan adanya signifikansi yang kuat, yaitu 0,016 (kurang dari 0,05 dan mendekati 0,00). Dengan demikian, materi nasionalisme merupakan mata pelajaran yang dapat digunakan untuk memperkuat sikap positif peserta Latsar dalam menjalankan tugasnya kelak sebagai pelaksana kebijakan publik, pelayan masyarakat, dan perekat persatuan bangsa.

4. Mata pelajaran etika publik (X3) memberikan pengaruh yang positif terhadap pembentukan sikap positif peserta Latsar. Hal ini ditunjukkan dengan adanya koefisien yang positif sebesar 0,185. Koefisien ini sedikit lebih besar daripada koefisien yang dimiliki mata pelajaran nasionalisme. Pengaruh positif ini juga didukung dengan adanya angka signifikansi yang kuat, yaitu sebesar 0,006. Apabila dibandingkan dengan angka signifikansi yang dimiliki materi nasionalisme, angka ini lebih kuat (semakin mendekati 0,00 dan menjauhi 0,005).

5. Materi komitmen mutu (X4) memiliki pengaruh yang positif dan signifkan terhadap pembentukan sikap positif peserta Latsar dalam mengemban tugas sebagai aparatur sipil negara. Hal ini ditunjukkan dengan adanya nilai koefisien yang positif, yaitu sebesar 0,274. Materi ini membekali peserta untuk senantiasa melakukan inovasi dalam rangka meningkatkan pelayanan yang mereka lakukan. Materi ini mendorong peserta untuk selalu berinovasi dan berkreasi dalam meningkatkan pelayanan yang dilakukannya tanpa melanggar peraturan perundangan yang berlaku. Pengaruh positif ini juga dibarengi dengan adanya signifikansi kuat yang ditandai dengan nilai sig. sebesar 0,00. Angka terakhir ini sudah maksimal menunjukkan kuatnya signifikansi pengaruh pemahaman akan materi komitmen mutu terhadap penguatan sikap peserta Latsar.

6. Mata pelajaran antikorupsi (X5) memiliki pengaruh yang positif terhadap penguatan sikap positif peserta Latsar. Hal ini ditunjukkan dengan nilai koefisien yang positif, yaitu sebesar 0,225. Angka ini relatif besar dibandingkan dengan koefisien variabel bebas lainnya walaupun masih di bawah angka koefisien yang dimiliki mata pelajaran komitmen mutu. Koefisien yang besar dan positif materi antikorupsi juga dibarengi dengan sifatnya yang signifikan. Hal ini ditunjukkan dengan nilai sig. yang sebesar 0,007. Dengan demikian, materi antikorupsi memiliki pengaruh yang positif dan signifikan terhadap pembentukan dan penguatan sikap peserta Latsar. 
Kelima variabel bebas yang diteliti, memiliki koefisien dan tingkat signifikansi yang berbeda-beda. Dari hasil pengolahan data dapat dibuat tabel komparasi sebagaimana terlihat pada Tabel 8.

Tabel 8. Perbandingan Koefisien dan Signifikasi Variabel Bebas

\begin{tabular}{lcc}
\hline \multicolumn{1}{c}{ Variabel } & Koefisien & Signifikansi \\
\hline Akuntabilitas $\left(X_{1}\right)$ & $-0,089$ & 0,363 \\
Nasionalisme $\left(X_{2}\right)$ & 0,184 & 0,016 \\
Etika Publik $\left(X_{3}\right)$ & 0,185 & 0,006 \\
Komitmen Mutu $\left(X_{4}\right)$ & 0,274 & 0,000 \\
Antikorupsi $\left(X_{5}\right)$ & 0,225 & 0,007 \\
\hline Sumber: Data primer (diolah) & &
\end{tabular}

Dengan membandingkan nilai koefisien dan signifikansi yang dimiliki setiap variabel, maka dapat disimpulkan bahwa pemahaman akan materi Komitmen Mutu memberikan pengaruh paling besar terhadap pembentukan dan penguatan sikap peserta Latsar. Variabel ini menduduki urutan pertama karena memiliki koefisien regresi terbesar dan nilai signifikansi yang terendah (paling signifikan). Urutan kedua yang memberikan pengaruh terhadap penguatan sikap peserta Latsar adalah materi Antikorupsi. Materi ini memiliki nilai koefisien yang besar dan didukung oleh nilai signifikansi yang sangat dekat dengan 0,00. Urutan ketiga ditempati oleh mata pelajaran Etika Publik yang memiliki nilai koefisien cukup besar dan didukung oleh signifikansi yang juga mendekati 0,00. Etika publik ditempatkan pada urutan setelah Antikorupsi karena memiliki selisih koefisien yang terpaut jauh walaupun memiliki angka signifikansi yang sedikit lebih rendah daripada materi Antikorupsi. Sementara itu, urutan keempat yang berpengaruh positif terhadap sikap adalah materi Nasionalisme yang memiliki angka koefisien masih positif dengan angka signifikansi yang terlemah apabila dibandingkan dengan komitmen mutu, antikorupsi, dan etika publik. Urutan terbawah adalah akuntabilitas yang memiliki angka koefisien negatif, tetapi tidak signifikan.

Dengan demikian, apabila diurutkan berdasarkan kuatnya pengaruh variabel tersebut terhadap pembentukan/penguatan sikap, maka urutannya adalah: 1) Komitmen mutu, 2) Antikorupsi, 3) Etika Publik, 4) Nasionalisme, dan 5) Akuntabilitas. Urutan tersebut dapat digunakan untuk memberikan penekanan mata pelajaran mana yang perlu mendapatkan perhatian untuk dikembangkan. Sementara itu, mata pelajaran yang berada di urutan bawah, bahkan berkoefisien negatif perlu dilakukan pembenahan, baik substansi maupun metode pembelajaran yang digunakannya.

Rekomendasi yang dapat diberikan dalam penelitian ini adalah bahwa mata pelajaran akuntabilitas perlu dilakukan perbaikan sehingga memberikan pengaruh yang positif dan signifikan dalam mendukung pembentukan dan penguatan sikap peserta Latsar. Perbaikan tersebut perlu dilakukan baik terhadap kurikulum, substansi materi, maupun model atau metode pembelajaran yang digunakannya. Selain itu, mata pelajaran nasionalisme, etika publik, komitmen mutu, dan antikorupsi perlu 
Achmat Subekan, Azwar Iskandar - Pengaruh Pemahaman

dipertahankan dan terus dikembangkan model pembelajarannya sehingga dapat memberikan pengaruh yang lebih besar dalam membangun sikap peserta Latsar.

\section{KESIMPULAN}

Dari uraian dan pembahasan yang telah dilakukan, maka dapat disimpulkan bahwa pemahaman akan materi utama Latsar yang berupa: 1) Akuntabilitas, 2) Nasionalisme, 3) Etika Publik, 4) Komitmen Mutu, dan 5) Antikorupsi, secara bersamasama (simultan) memberikan pengaruh positif dan signifikan terhadap pembentukan dan penguatan sikap peserta Latsar dalam mengemban tugas sebagai aparatur sipil negara (pegawai negeri sipil). Secara parsial, kelimanya memiliki besaran pengaruh (koefisien) yang berbeda-beda. Di antara kelimanya, hanya pemahaman akan materi akuntabilitas yang memiliki pengaruh negatif, tetapi tidak signifikan, sedangkan empat variabel bebas lainnya memiliki pengaruh yang positif dan signifikan. Dari kelima materi nilai dasar yang diberikan, materi Komitmen Mutu memberikan pengaruh paling besar terhadap pembentukan dan penguatan sikap peserta dalam melaksanakan tugas/fungsi sebagai PNS. Secara berurutan (dari variabel yang kuat ke variabel yang lemah), kekuatan dan signifikansi kelima materi dalam memberikan pengaruh terhadap pembentukan/penguatan sikap adalah: 1) Komitmen mutu, 2) Antikorupsi, 3) Etika Publik, 4) Nasionalisme, dan 5) Akuntabilitas.

\section{REFERENSI}

Arikunto, S., Jabar, Abdul, C.S. (2008). Evaluasi Program Pendidikan. Bumi Aksara.

Ariola (2006). Principles and Methods of Research.

Bhuiyan, S. H., Amagoh, F. (2011). Public sector reform in Kazakhstan: issues and perspectives. International Journal of Public Sector Management, 24(3), 227249.

Faradila, A. H., Holilulloh, \& Adha, M. M. (2014). Pengaruh Pemahaman Ideologi Pancasila Terhadap Sikap Moral Dalam Mengamalkan Nilai-Nilai Pancasila. Jurnal Kultur Demokrasi, Vol. 2 No. 7.

Ghozali, I. (2006). Aplikasi Analisis Multivariat Dengan Program SPSS-Cetakan Keempat. Badan Penerbit Universitas Diponegoro Semarang.

Morrell, K. (2009). Governance and the public good. Public Administration, 87, 538556.

Nachrowi, D. N., \& Usman, H. (2006). Pendekatan Populer dan Praktis Ekonometrika untuk Analisis Ekonomi dan Keuangan. Jakarta: Lembaga Penerbit Fakultas Ekonomi.

Peraturan Kepala LAN Nomor 22 Tahun 2016 Tentang Pedoman Penyelenggaraan Pelatihan Dasar Calon Pegawai Negeri Sipil Golongan I dan Golongan II. Jakarta: LAN RI.

Pratiwi, Rina. (2014). Pengaruh Pemahaman Materi Hak Asasi Manusia Terhadap Sikap Kemanusiaan Siswa Kelas VII di SMP Negeri 2 Hulu Sungkai Kabupaten Lampung Utara T.P 2012/2013, Lampung: Universitas Lampung. 
Raharjo, Taufik. (2016). Efektivitas Diklat Prajabatan Pola Baru bagi Calon Pegawai Negeri Sipil Kementerian Keuangan. Jurnal Info Artha, Vol. 2.

Santoso, Singgih, \& Tjiptono, F. (2002). Konsep dan Aplikasi Dengan SPSS. Jakarta: PT. Elex Media Komputindo.

Shaoul, J., Stafford, A., Stapleton, P. (2012). Accountability and corporate governance of public private partnerships. Critical Perspectives on Accounting, 23(3), 213229.

Triton, P.B. (2005). Riset Statistik Parametrik: SPSS13.00 for Windows. Yogyakarta: Andi.

Undang-Undang Nomor 5 Tahun 2014 Tentang Aparatur Sipil Negara. Jakarta: Kementerian Hukum dan HAM RI.

United Nation Human Rights. (2012). Good Governance. Retrieved from http://www.ohchr.org/en//ssues/Development/GoodGovernance/Pages/GoodGo vernancelndex.aspx. 